\title{
PENGARUH MODEL PEMBELAJARAN GUIDE INQUIRY DAN PEMAHAMAN KONSEP AWAL TERHADAP HASIL BELAJAR SISWA
}

\author{
Juniar Hutahaean, Mariati Purnama Simanjuntak \\ dan Mailita Sari Pulungan \\ Jurusan Fisika FMIPA Universitas Negeri Medan \\ Jalan Willem Iskandar Pasar V Medan, Sumatera Utara \\ junhut@gmail.com
}

\begin{abstract}
ABSTRAK
Penelitian ini bertujuan untuk: 1) mengetahui pengaruh model pembelajaran guided inquiry dan pemahaman konsep awal terhadap hasil belajar, 2) mengetahui perbedaan hasil belajar fisika antara siswa yang memiliki pemahaman konsep awal tinggi dan siswa yang memiliki pemahaman konsep awal rendah, dan 3) mengetahui interaksi antara model pembelajaran guided inquiry dengan pemahaman konsep awal siswa dalam mempengaruhi hasil belajar siswa. Populasi penelitian adalah siswa kelas X MIA di salah satu SMA negeri di Medan Tahun Pelajaran 2015/2016. Teknik pengambilan sampel dengan menggunakan cluster random sampling yang terdiri dari dua kelas dengan jumlah sampel di kelas kontrol sebanyak 36 orang dan di kelas eksperimen sebanyak 35 orang. Metode yang digunakan dalam penelitian ini adalah kuasieksperimental dengan pretest-posttest control group design. Instrumen penelitian berupa tes hasil belajar dan tes pemahaman konsep awal berbentuk pilihan berganda dengan lima option. Teknik analisis data yang digunakan adalah analisis varians dua jalur. Berdasarkan hasil analisis data, disimpulkan: 1) terdapat perbedaan yang signifikan antara hasil belajar siswa yang dibelajarkan dengan menggunakan model guided inquiry dibandingkan dengan hasil belajar siswa yang dibelajarkan dengan menggunakan pembelajaran konvensional; 2) terdapat perbedaan yang signifikan antara hasil belajar siswa yang memiliki pemahaman konsep awal di atas rerata dengan siswa yang memiliki pemahaman konsep awal di bawah rerata; dan 3) terdapat interaksi yang signifikan antara model guided inquiry dan pembelajaran konvensional dengan pemahaman konsep awal terhadap hasil belajar siswa.
\end{abstract}

Kata kunci: model guided inquiry, pemahaman konsep awal, hasil belajar

\section{ABSTRACT}

This research aims to 1) determine the effect of guided inquiry of learning model and basic concept understanding toward learning result. 2) determine the difference of physics learning result between student that owning the high basic concept understanding and student that owning low basic concept understanding, and 3) determine interaction between guide inquiry with basic concept understanding in effect toward student learning result. The population is all student in class of X MIA on one of SMA Negeri in Medan 2015/2016. Sampling technique by using cluster random sampling which consist of two class with amount of sampel in control class 36 people and in experiment class 35 people. The method used in this quasi experiment research is pretest-posttest control group design. Instrument learning result and understanding 
of initial concept formed in multiple choice with five options. Analysis data technique used is analysis of varians two way. Based on the result of analysis data, concluded 1) there are significant difference between student learning result by using guided inquiry model compared with student learning result by using conventional study 2) there are significant difference between student learning result that owning the basic concept understanding above average with student that owning the basic concept understanding below average; and 3) there are significant interaction between guided inquiry model and conventional study with understanding of initial concept toward student learning result.

Keyword: guided inquiry model, basic concept understanding, learning result

\section{PENDAHULUAN}

Pendidikan memegang peranan yang sangat penting dalam mempersiapkan manusia yang berkualitas bagi pembangunan dan kemajuan suatu negara. Pendidikan merupakan salah satu aset masa depan yang menentukan maju mundurnya suatu bangsa oleh sebab itu pembangunan sektor pendidikan harus menjadi salah satu prioritas utama. Berkembangnya pendidikan sudah pasti berpengaruh terhadap perkembangan ilmu pengetahuan dan teknologi (iptek). Hal ini dapat terlihat dengan semakin pesatnya perkembangan ilmu pengetahuan dan teknologi sekarang ini. Pesatnya perkembangan iptek sekarang ini tidak dapat terlepas dari kemajuan ilmu sains (termasuk fisika) yang banyak menghasilkan temuan baru dalam bidang sains dan teknologi.

Pembelajaran hendaknya mengacu pada pola pengembangan potensi siswa secara optimal melalui pembekalan dan pemberian kesempatan yang luas kepada siswa untuk belajar, sehingga mereka mampu mengembangkan pemahamannya, pemecahan masalah, kritis dan kreatif, yang nantinya dapat meningkatkan hasil belajarnya.

Realita yang nampak di lapangan menunjukkan pola transfer pengetahuan yang berbeda. Guru hanya berusaha memindahkan pengetahuan kepada siswa, tanpa memberikan kesempatan yang memadai kepada siswa untuk mengembangan potensi dirinya mengkonstruksi pengetahuannya melalui penyelidikan berbasis eksperimen. Guru menerapkan pembelajaran konvensional dengan menekankan penerapan persamaan matematis dalam membelajarkan fisika melalui metode ceramah, latihan dan pemberian. Kondisi ini melahirkan opini dan anggapan, bahwa fisika itu merupakan mata pelajaran yang sulit dan membosankan sehingga hasil belajar mereka menjadi rendah.

Berdasarkan fakta di lapangan menunjukkan bahwa banyak siswa mendapatkan nilai yang tidak mencapai Kriteria Ketuntasan Minimal (KKM), seperti halnya di salah satu SMA Negeri di Medan, dengan kata lain, hasil belajar fisika siswa masih rendah. Berdasarkan hasil wawancara pada salah seorang guru di sekolah tersebut mengatakan bahwa rendahnya hasil belajar yang diperoleh siswa disebabkan karena guru umumnya masih menggunakan pembelajaran konvensional yang dominan menggunakan metode ceramah, sehingga menyebabkan siswa kurang tertarik belajar fisika. Guru jarang sekali melakukan penyelidikan melalui eksperimen bahkan bisa dikatakan tidak pernah.

Salah satu cara yang dapat digunakan untuk mengatasi masalah di atas adalah dengan menggunakan model pembelajaran yang menuntut siswa untuk melakukan penyelidikan melalui eksperimen, yaitu dengan model inkuiri terbimbing (guided inquiry). Melalui model pembelajaran ini diharapkan dapat mendorong siswa untuk merumuskan 
masalah dan hipotesis, menganalisis bereksperimen, sehingga dapat menemukan konsep berdasarkan bahan atau data yang disediakan guru. Melalui penyelidikan melalui eksperimen, siswa mengalami sendiri, menemukan dan mengkonstruksi pengetahuannya. Menurut Kuhlthau, et all., (2007 ; 2012) inkuiri terbimbing merupakan salah satu model pembelajaran yang dirancang untuk mengajarkan konsepkonsep dan hubungan antar konsep. Inkuiri terbimbing merupakan cara berfikir, belajar dan mengajar yang mengubah budaya sekolah menjadi komunitas penyelidikan kolaboratif.

Inkuiri juga mengacu pada kegiatan siswa untuk mengembangkan pengetahuan dan pemahaman ide-ide ilmiah, serta pemahaman tentang hakekat alam (NRC, 1996). Hal ini didukung oleh Wenning (2011) yang menyatakan bahwa guided inquiry suatu pembelajaran inkuiri yang dalam pelaksanaannya guru menyediakan bimbingan atau petunjuk cukup luas kepada siswa

Hal yang senada dinyatakan oleh (NSTA, 2004) yang menyatakan bahwa dalam proses pembelajaran inkuiri, siswa belajar untuk melakukan investigasi dan mengumpulkan bukti-bukti dari berbagai sumber, mengembangkan penjelasan berdasarkan data, mengkomunikasikan dan menyimpulkan.

Selain model guided inquiry, pemahamana konsep awal juga akan mempengaruhi hasil belajar siswa karena siswa yang sudah memiliki pemahaman konsep awal yang tinggi maka hasil belajarnya juga akan lebih baik.

Berdasarkan uraian masalah di atas, maka penulis tertarik untuk melakukan penelitian dengan tujuan untuk: 1) mengetahui pengaruh model pembelajaran guided inquiry dan pemahaman konsep awal terhadap hasil belajar, 2) mengetahui perbedaan hasil belajar fisika antara siswa yang memiliki pemahaman konsep awal tinggi dan siswa yang memiliki pemahaman konsep awal rendah, dan 3) mengetahui interaksi antara model pembelajaran guided inquiry dengan pemahaman konsep awal siswa dalam mempengaruhi hasil belajar siswa

\section{METODE PENELITIAN}

Populasi dalam penelitian ini adalah semua peserta didik kelas $\mathrm{X}$ di salah satu SMA Negeri di Medan pada semester ganjil T.A. 2015/2016 yang terdiri dari enam kelas.

Pengambilan sampel menggunakan teknik cluster random sampling, sampel diambil dari populasi, yaitu sebanyak 2 kelas. Satu kelas dijadikan sebagai kelas eksperimen (kelas MIA-3) yang berjumlah 35 orang, yaitu kelas yang diajar menggunakan model pembelajaran guided inquiry dan satu kelas lagi dijadikan sebagai kelas kontrol (kelas MIA-4) yang berjumlah 36 orang, yaitu kelas yang diajar dengan menggunakan pembelajaran konvensional. Jenis penelitian ini termasuk quasi eksperimen dengan control group pretest-posttest design. Desain penelitian ini ditunjukkan pada Tabel 1.

Tabel 1 Desain Penelitian Control Group Pretest-Posttest

\begin{tabular}{|l|c|c|c|}
\hline Kelas & Pretes & $\begin{array}{c}\text { Perlakua } \\
\mathrm{n}\end{array}$ & Postes \\
\hline Eksperimen & $\mathrm{T}_{1}$ & $\mathrm{X}_{1}$ & $\mathrm{~T}_{2}$ \\
\hline Kontrol & $\mathrm{T}_{1}$ & $\mathrm{X}_{2}$ & $\mathrm{~T}_{2}$ \\
\hline
\end{tabular}

Keterangan :

$\mathrm{T}_{1}=$ pretes

$\mathrm{T}_{2}=$ postes

$\mathrm{X}_{1}=$ Perlakuan pada kelas eksperimen yaitu dengan penerapan guided inquiry

$\mathrm{X}_{2}=$ Perlakuan pada kelas kontrol yaitu penerapan model pembelajaran konvensional.

Analisis data penelitian ini menggunakan analysis of varians two way (anava dua jalur). Desain Anava dua jalur ditunjukkan pada Tabel 2.

Tabel 2. Desain Penelitian Anava Dua Jalur

\begin{tabular}{|c|c|c|c|}
\hline Pemaham & \multicolumn{4}{|c|}{ Model Pembelajaran (A) } \\
\cline { 2 - 5 } $\begin{array}{c}\text { an Konsep } \\
\text { Awal }(\mathrm{B})\end{array}$ & $\begin{array}{c}\text { Konvensio- } \\
\text { nal }\left(\mathrm{A}_{1}\right)\end{array}$ & \multicolumn{3}{|c|}{ Guided Inquiry $\left(\mathrm{A}_{2}\right)$} \\
\hline Tinggi $\left(\mathrm{B}_{1}\right)$ & $\mathrm{A}_{1} \mathrm{~B}_{1}$ & $\mathrm{~A}_{2} \mathrm{~B}_{1}$ & $\mu_{\mathrm{B} 1}$ \\
\hline
\end{tabular}




\begin{tabular}{|c|c|c|c|}
\hline Rendah $\left(B_{2}\right)$ & $\overline{A_{1} B_{2}}$ & $\mathrm{~A}_{2} \mathrm{~B}_{2}$ & $\mu_{\mathrm{B} 2}$ \\
\hline Rata-rata & & & \\
\hline
\end{tabular}

Keterangan:

$A_{1} B_{1}$ : Hasil belajar fisika kelompok siswa yang diberi perlakuan pembelajaran konvensional dengan memiliki pemahaman konsep awal

$\mathrm{A}_{2} \mathrm{~B}_{1}$ : Hasil belajar fisika kelompok siswa yang diberi perlakuan pembelajaran model guided inquiry dengan memiliki pemahaman konsep awal tinggi

$A_{1} B_{2}$ : Hasil belajar fisika kelompok siswa yang diberi perlakuan dengan pembelajaran konvensional dan memiliki pemahaman konsep awal rendah

$A_{2} B_{2}$ : Hasil belajar fisika kelompok siswa yang diberi perlakuan dengan pembelajaran guided inquiry dan memiliki pemahaman konsep awal rendah.

$\mu_{\mathrm{A} 1}$ : Rata-rata hasil belajar fisika siswa yang diajar dengan model konvensional

$\mu_{\mathrm{A} 2}$ : Rata-rata hasil belajar fisika siswa yang diajar dengan model guided inquiry

$\mu_{\mathrm{B} 1} \quad$ : Rata-rata hasil belajar fisika siswa yang mempunyai pemahaman konsep awal tinggi

$\mu_{\mathrm{B} 2}$ : Rata-rata hasil belajar fisika siswa yang mempunyai pemahaman konsep awal rendah

Instrumen yang digunakan dalam penelitian ini berupa lembar observasi, tes pemahaman konsep, dan tes hasil belajar. Instrumen pemahaman konsep awal dan tes hasil belajar berbentuk pilihan ganda dengan lima option yang masing-masing berjumlah 25 dan 20 soal yang sudah valid pada topik Gerak Lurus. Tes hasil belajar yang disusun berdasarkan indikator: mengingat, memahami, mengaplikasikan, menganalisis, mengevaluasi dan mencipta (Anderson \& Krathwol, 2001).

\section{HASIL DAN PEMBAHASAN}

\section{Hasil Penelitian}

Deskripsi data yang disajikan dalam penelitian ini berasal dari data yang dikumpulkan selama penelitian yang terdiri data uji pemahaman konsep, pretes dan postes. Data pemahaman konsep awal dan pretes dikumpulkan sebelum proses pembelajaran dengan menerapkan model guided inquiry di kelas eksperimen dan konvensional di kelas kontrol.

Pengambilan data pretes bertujuan untuk mengetahui apakah kemampuan awal siswa pada kedua kelas sebelum dilakukan perlakuan sama atau berbeda. Untuk mengetahui kemampuan awal siswa apakah sama atau berbeda menggunakan uji beda (uji-t) dengan syarat data berdistribusi normal dan homogen.

Gambar 1. Perbandingan Pretes dan Postes Kedua Kelas

Data postes bertujuan untuk mengetahui apakah ada pengaruh model pembelajaran terhadap hasil belajar. Data postes dianalisis dengan menggunakan uji anova dua jalur dengan syarat data berdistribusi normal dan homogen (Sudjana, 2005). Data pretes dan postes kelas eksperimen dan kelas kontrol ditunjukkan pada Grafik 1 .

Nilai pemahaman konsep siswa diperoleh dengan menggunakan instrumen pemahaman konsep awal berbentuk pilihan ganda dengan lima optian yang berjumlah 25 soal. Data pemahaman konsep awal ini dilakukan sebelum pembelajaran dimulai. Pengelompokan siswa dikelompokkan dalam dua kategori yaitu pemahaman konsep awal di bawah rerata dan pemahaman konsep awal di atas rerata. Pengelompokan siswa bertujuan agar dapat membedakan siswa berdasarkan pemahaman konsep awal dalam pengolahan data, sedangkan pada saat. Data pemahaman konsep awal siswa pada kelas kontrol dan kelas eksperimen ditunjukkan pada Tabel 1. 
Tabel 1. Nilai Pemahaman Konsep Awal Kedua Kelas

\begin{tabular}{|c|c|c|}
$\begin{array}{c}\text { Nilai } \\
\text { Pemahaman } \\
\text { Konsep Awal }\end{array}$ & $\begin{array}{c}\text { Frekuensi } \\
\text { Kelas } \\
\text { Kontrol }\end{array}$ & $\begin{array}{c}\text { Frekuensi } \\
\text { Kelas } \\
\text { Eksperimen }\end{array}$ \\
\hline 16 & 1 & - \\
\hline 24 & 1 & 1 \\
\hline 28 & 2 & 4 \\
\hline 32 & 3 & 1 \\
\hline 36 & 5 & 4 \\
\hline 40 & 2 & 4 \\
\hline 44 & 8 & 4 \\
\hline 48 & 2 & 1 \\
\hline 52 & 3 & 1 \\
\hline 56 & 2 & 7 \\
\hline 60 & 4 & 6 \\
\hline 64 & 3 & 2 \\
\hline Rerata Nila & 44,44 & 46,51 \\
\hline
\end{tabular}

Selanjutnya setelah proses pembelajaran, siswa diberikan postes untuk mengetahui bagaimana pengaruh model pembelajaran terhadap hasil belajar siswa. Hasil belajar siswa berdasarkan pemahaman konsep awal dapat dilihat pada Tabel 3.

Siswa yang memiliki nilai lebih kecil dengan batas rerata kelas dikelompokkan dalam kategori siswa memiliki pemahaman konsep awal di bawah rerata. Siswa yang memiliki nilai lebih besar atau sama dengan rerata dikelompokkan dalam kategori siswa memiliki pemahaman konsep awal di atas rerata. Berdasarkan kategori tersebut siswa di kelas eksperimen yang memiliki pemahaman konsep awal di bawah rerata sebanyak 18 siswa sedangkan pada kelas kontrol terdapat 22 siswa. Pada kelas eksperimen, siswa yang memiliki pemahaman konsepawal di atas rerata sebanyak 17 orang sedangkan di kelas kontrol sebanyak 14 siswa yang memiliki pemahaman konsep di atas rerata. Deskripsi Tabel 3. Hasil Statistik Anava Dua Jalur Intercept

\section{Tests of Between-Subjects Effects(b)} Dependent Variable: Postes

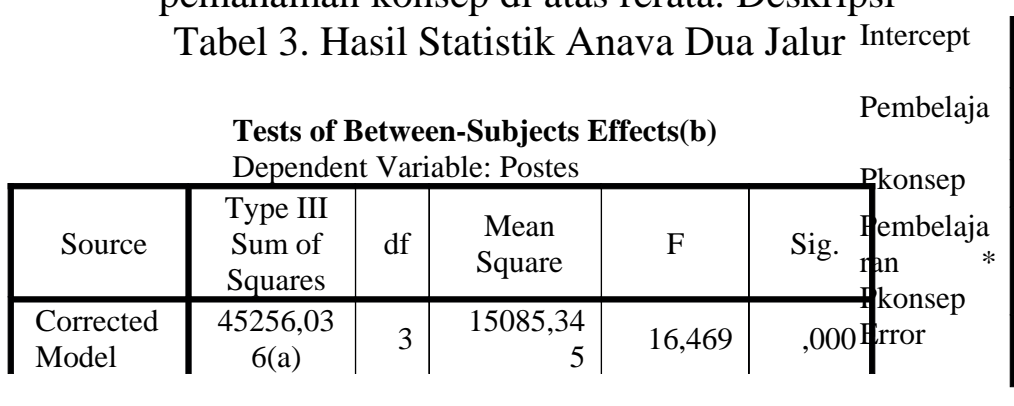

pemahaman konsep awal pada kedua kelas ditunjukkan pada Tabel 2.

Tabel 2. Deskripsi Pemahaman Konsep Awal pada Kedua Kelas

\begin{tabular}{|c|c|c|c|c|c|}
\hline & \multirow[b]{2}{*}{$\begin{array}{c}\text { Pemahaman } \\
\text { Konsep Awal }\end{array}$} & & \multirow[b]{2}{*}{$\begin{array}{c}\text { Rerat } \\
\text { a }\end{array}$} & \multicolumn{2}{|c|}{ Skor } \\
\hline & & & & $\begin{array}{l}\text { mini- } \\
\text { mum }\end{array}$ & $\begin{array}{l}\text { maks- } \\
\text { imum }\end{array}$ \\
\hline \multirow{2}{*}{$\begin{array}{l}\text { Ekspe- } \\
\text { rimen }\end{array}$} & $\begin{array}{ll}\text { di } & \text { bawah } \\
\text { rerata } & \\
\end{array}$ & 18 & $36,00_{24}$ & & \multirow[t]{2}{*}{64} \\
\hline & di atas rerata & 17 & 57,65 & & \\
\hline \multirow{2}{*}{$\begin{array}{l}\text { Kon- } \\
\text { trol }\end{array}$} & $\begin{array}{ll}\text { di } & \text { bawah } \\
\text { rerata } & \\
\end{array}$ & 22 & 36,55 & \multirow[t]{2}{*}{16} & \multirow[t]{2}{*}{64} \\
\hline & di atas rerata & 14 & 56,86 & & \\
\hline
\end{tabular}

Hipotesis penelitian diuji dengan menggunakan uji General Linear Model Univariate (GLMU) pada taraf signifikansi $\alpha=0.05$ dengan bantuan program SPSS 15.0. Siswa digolongkan berdasarkan pemahaman konsep awal. Kelompok siswa terdiri dari dua yaitu kelompok siswa yang memiliki pemahaman konsep awal di bawah rerata dan kelompok siswa yang memiliki pemahaman konsep awal di atas rerata. Untuk melihat perbedaan pemahaman konsep awal dan hasil belajar siswa terhadap model pembelajaran yang diberikan digunakan uji GLMU. Uji ini juga digunakan untuk mengetahui bagaimana pengaruh pemahaman konsep awal terhadap hasil belajar siswa. Apakah siswa yang memiliki pemahaman konsep awal di bawah. rerata memiliki hasil yang lebih rendah dibandingkan dengan siswa yang memiliki pemahaman konsep awal di atas rerata memiliki hasil belajar yang lebih tinggi. Uji GLMU juga digunakan untuk mengetahui apakah ada interaksi antara model pembelajaran dengan pemahaman konsep awal siswa dalam mempengaruhi hasil belajar siswa. 

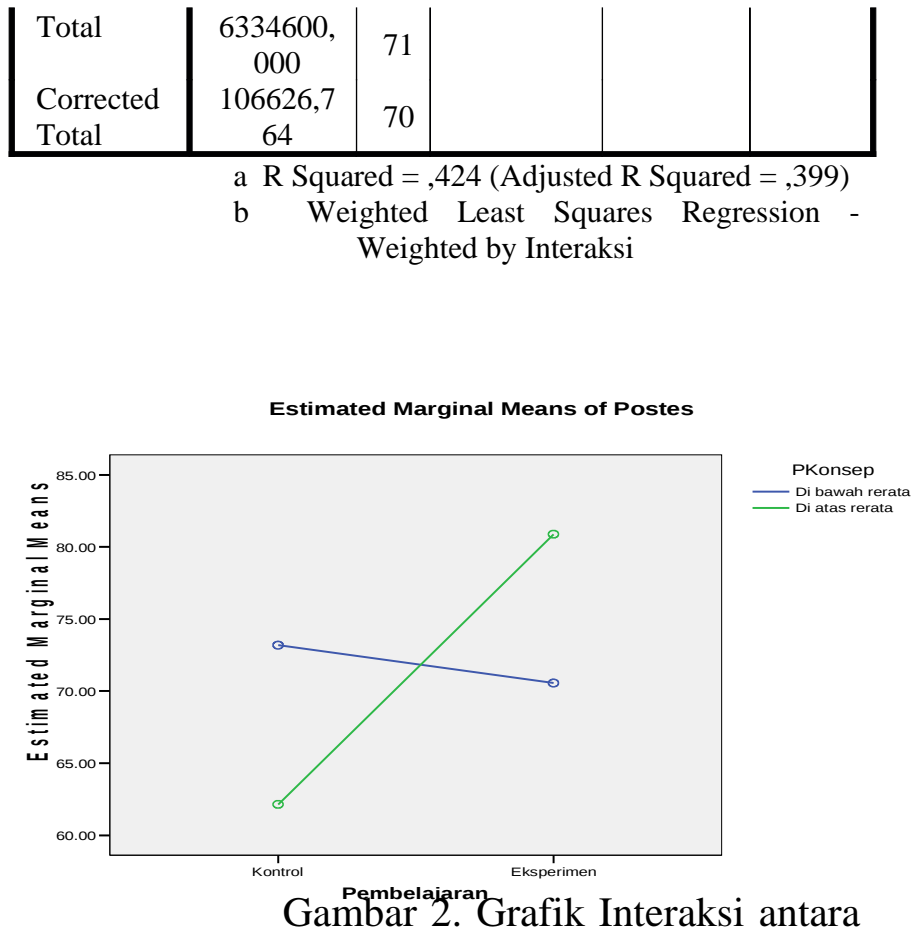

Model Pembelajaran dan Pemahaman Konsep Awal

Deskripsi statistik output dari anova data pemahaman konsep awal pada kedua kelas disajikan dalam Tabel 3.

Berdasarkan Tabel 3, perhitungan pembelajaran*PKonsep diperoleh signifikansi 0,000 lebih kecil dibandingkan dengan signifikansi $\alpha=$ 0.05 maka diperoleh kesimpulan bahwa terdapat interaksi antara model pembelajaran guided inquiry dengan pemahaman konsep awal untuk meningkatkan hasil belajar siswa. Hal ini dapat dilihat pada Gambar 2.

Gambar 2 menunjukkan grafik interaksi antara model pembelajaran dan pemahaman konsep awal dalam meningkatkan hasil belajar fisika. Kedua garis berpotongan yang berarti terdapat interaksi yang signifikan antara model pembelajaran dan pemahaman konsep awal dalam meningkatkan hasil belajar fisika secara keseluruhan kelompok sampel kelas. Untuk melihat interaksi model pembelajaran dengan pemahaman konsep awal terhadap hasil belajar fisika siswa digunakan uji two way Anova dengan GLMU.

\section{Pembahasan}

Berdasarkan data hasil penelitian yang diperoleh dalam pengujian hipotesis penelitian dapat dikemukakan:

a. Perbedaan hasil belajar siswa dengan model guided inquiry dan pembelajaran konvensional

Berdasarkan penelitian yang dilakukan bahwa hasil belajar siswa yang dibelajarkan menggunakan pembelajaran konvensional memiliki nilai rerata sebesar 68,89 sedangkan hasil belajar siswa yang dibelajarkan menggunakan model guided inquiry Berdasarkan hasil uji Anova dua jalur yang dilakukan diperoleh bahwa signifikansi 0.000 $(0.000<0.05)$, yang artinya ada perbedaan hasil belajar yang signifikan antara siswa yang dibelajarkan dengan model guided inquiry terhadap siswa yang dibelajarkan dengan pembelajaran konvensional.

\section{b. Perbedaan hasil belajar siswa yang memiliki pemahaman konsep awal di atas rerata dan pemahaman konsep awal di bawah rerata}

Berdasarkan uji anova dua jalur yang dilakukan pada hasil belajar fisika antara siswa yang memiliki pemahaman konsep awal di atas rerata dan siswa yang memiliki pemahaman konsep awal di bawah rerata secara keseluruhan terdapat perbedaan yang signifikan. Dari hasil uji analisis varians hasil belajar fisika antara siswa yang memiliki pemahaman konsep awal di atas rerata dan siswa yang memiliki pemahaman konsep awal di bawah rerata. Hal ini ditunjukkan dengan nilai signifikansi $0.000(0.000<0.05)$, yang artinya ada perbedaan yang signifikan antara hasil belajar siswa yang memiliki pemahaman konsep awal di atas rerata dengan hasil belajar siswa yang memiliki pemahaman konsep awal di bawah rerata. Taraf signifikansi dalam penelitian ini sebesar 0.000 yang artinya ada pengaruh pemahaman konsep awal yang signifikan dalam pencapaian hasil belajar siswa. 
c. Terdapat interaksi antara model pembelajaran dan sikap ilmiah terhadap hasil belajar siswa

Berdasarkan hasil pengujian hipotesis pada Tabel 3 untuk interaksi antara model pembelajaran dengan pemahaman konsep awal (Pembelajaran*Tingkat pemahaman konsep awal), terdapat nilai signifikansi sebesar 0,000. Oleh karena nilai signifikansi $0,000<0.05$ yang berarti secara keseluruhan terdapat interaksi yang signifikan antara pembelajaran konvensional dan model guided inquiry dengan pemahaman konsep awal terhadap hasil belajar siswa.

Penerapan model guided inquiry dapat mempengaruhi hasil belajar, hal ini didukung oleh penelitian Turnip dan Simanjuntak (2015) diperoleh bahwa terdapat pengaruh yang signifikan akibat penerapan model pembelajaran guided inquiry terhadap hasil belajar mahasiwa pada materi Kinematika Partikel. Dengan kata lain, penerapan model pembelajaran guided inquiry lebih baik meningkatkan hasil belajar dibandingkan dengan pembelajaran konvensional. Hal ini diperkuat oleh Wijayanti, dkk., yang menyatakan bahwa selain meningkatkan hasil belajar, guided inquiry juga dapat mengurangi kesulitan belajar fisika.

\section{KESIMPULAN DAN SARAN Kesimpulan}

Berdasarkan pengujian hipotesis, pengolahan data dan pembahasan hasil penelitian yang dilakukan, dapat ditarik kesimpulan sebagai berikut:

1) Terdapat perbedaan hasil belajar yang signifikan antara siswa yang dibelajarkan dengan menggunakan model guided inquiry dengan siswa yang dibelajarkan dengan menggunakan pembelajaran konvensional sehingga efek model guided inquiry lebih baik daripada pembelajaran konvensional.

2) Terdapat perbedaan hasil belajar antara siswa yang memiliki pemahaman konsep awal di atas rerata dengan siswa yang memiliki pemahaman konsep awal di bawah rerata. Hasil belajar siswa yang memiliki pemahaman konsep awal di atas rerata lebih baik daripada hasil belajar siswa yang memiliki pemahaman konsep awal di bawah rerata.

3) Terdapat interaksi antara pembelajaran konvensional dan model guided inquiry dengan sikap ilmiah terhadap hasil belajar fisika siswa. Hal ini menunjukkan pemahaman konsep awal berperan dalam pembelajaran konvensional dan model guided inquiry dalam meningkatkan hasil belajar fisika.

\section{Saran}

Berdasarkan kesimpulan yang diuraikan di atas maka berikut ini diajukan beberapa saran sebagai berikut:

Hendaknya

para guru dapat menerapkan modelmodel pembelajaran, khususnya model quided inquiry dalam proses pembelajaran.
1.i.2)
Kepada

para pembaca terutama yang terlibat dalam pembelajaran diharapkan dapat mengembangkan model quided inquiry sebagaimana pemerintah telah mensosialisasikan untuk penggunaaannya dalam kurikulum 2013 yang mulai terapkan.
1.i.3)
Kepada
para peneliti diharapkan dapat melanjutkan penelitian model quided inquiry dengan variasi pembelajaran yang beragam.

\section{DAFTAR PUSTAKA}

Anderson, L.W, \& Krathwol, D.R. (eds). (2001). A Taxonomy for Learning Teaching and Assessing. A Revision of Bloom's Taxonomy of Educational Objectives.New York: Addison Wesley Longman, Inc. 
Kuhlthau, C. C., Maniotes, L. K \& Caspari, A. K. (2012). Guided Inquiry Design: a Framework for Inquiry in You're School. ABC-CLIO: California.

Kuhlthau, C. C., Maniotes, L. K. \& Caspari, A. K. (2007). Guided Inquiry Learning in the $21^{\text {st }}$ Century. Libraries Unlimited Westport Connecticut. London.

National Science Teachers Association (NSTA). (2004). Standard for Science Teacher Preparation. Association for the Education of Teachers in Science.

NRC. (1996). National Science Education Standards. Washington: National Academy Press.

Sudjana, (2005). Metoda Statistika. Penerbit Tarsito: Bandung.
Turnip, B. M. \& Simanjuntak, M. P. (2015). The Effect of Guided Inquiry Learning Model Towards The Outcome of Student Learning . Seminar Internasional The 2nd Annual International Seminar on Trends in Science and Science Education.

Wenning, C. J. 2011. Experimental inquiry in introductory physics courses. Journal of Physics Teacher Education Online. 6(2): (1-8).

Wijayanti, P. I. Mosik, dan Hindarto, N. (2010). Eksplorasi Kesulitan Belajar Siswa pada Pokok Bahasan Cahaya dan Upaya Peningkatan Hasil Belajar Melalui Pembelajaran Inkuiri Terbimbing, Jurnal Pendidikan Fiska Indonesia. 6 (1-5) ISSN: 1693-1246. 